\title{
The role of virtual integration, commitment, and knowledge-sharing in improving international supplier responsiveness
}

Link to publication record in Manchester Research Explorer

Citation for published version (APA):

Sinkovics, R. R., Dimitratos, P. (Ed.), \& Jones, M. V. (Ed.) (2010). The role of virtual integration, commitment, and knowledge-sharing in improving international supplier responsiveness. In Resources, Efficiency and Globalization (17 ed., pp. 27-43). Palgrave Macmillan Ltd. http://www.palgrave.com/products/title.aspx?PID=376213

Published in:

Resources, Efficiency and Globalization

\section{Citing this paper}

Please note that where the full-text provided on Manchester Research Explorer is the Author Accepted Manuscript or Proof version this may differ from the final Published version. If citing, it is advised that you check and use the publisher's definitive version.

\section{General rights}

Copyright and moral rights for the publications made accessible in the Research Explorer are retained by the authors and/or other copyright owners and it is a condition of accessing publications that users recognise and abide by the legal requirements associated with these rights.

\section{Takedown policy}

If you believe that this document breaches copyright please refer to the University of Manchester's Takedown Procedures [http://man.ac.uk/04Y6Bo] or contact uml.scholarlycommunications@manchester.ac.uk providing relevant details, so we can investigate your claim.

\section{OPEN ACCESS}




\section{Resources, Efficiency and Globalization}

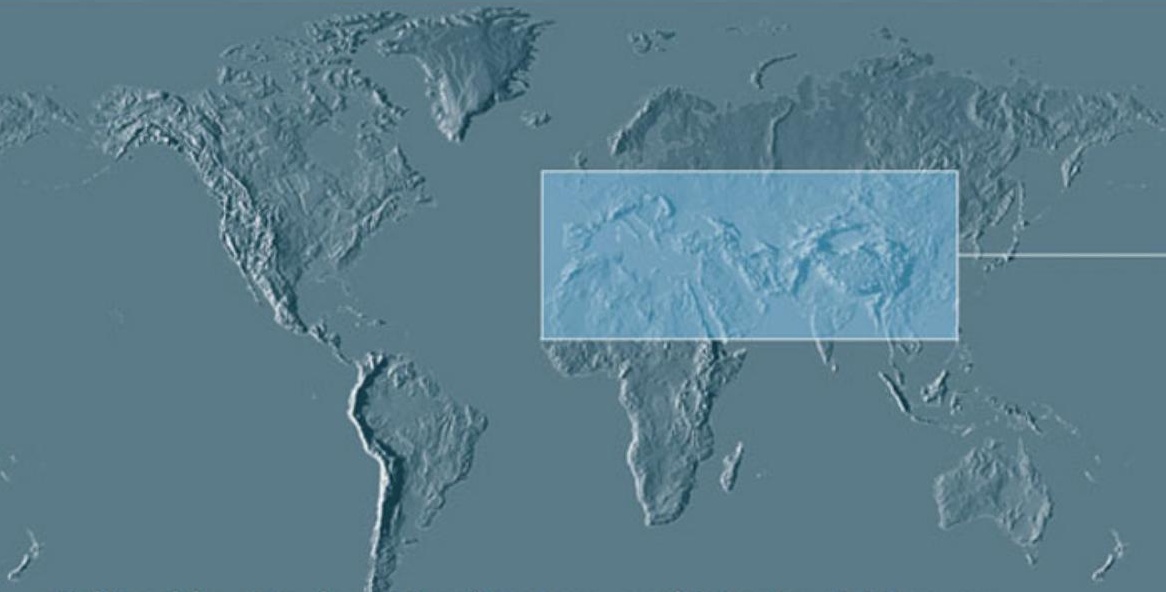

Edited by Pavlos Dimitratos and Marian V. Jones

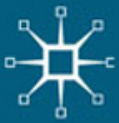




\section{Resources, Efficiency and Globalization}

Edited By

Pavlos Dimitratos

Assistant Professor, Athens University of Economics and Business

and

Marian V. Jones

Professor of Internationalisation and Entrepreneurship, University of Glasgow

\section{palgrave macmillan}




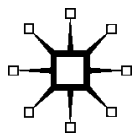

Selection and editorial content @ Pavlos Dimitratos and Marian V. Jones 2010 Individual chapters (C) contributors 2010

Foreword (c) Frank McDonald

All rights reserved. No reproduction, copy or transmission of this publication may be made without written permission.

No portion of this publication may be reproduced, copied or transmitted save with written permission or in accordance with the provisions of the Copyright, Designs and Patents Act 1988, or under the terms of any licence permitting limited copying issued by the Copyright Licensing Agency, Saffron House, 6-10 Kirby Street, London EC1N 8TS.

Any person who does any unauthorized act in relation to this publication may be liable to criminal prosecution and civil claims for damages.

The authors have asserted their rights to be identified as the authors of this work in accordance with the Copyright, Designs and Patents Act 1988.

First published 2010 by

PALGRAVE MACMILLAN

Palgrave Macmillan in the UK is an imprint of Macmillan Publishers Limited, registered in England, company number 785998, of Houndmills, Basingstoke, Hampshire RG21 6XS.

Palgrave Macmillan in the US is a division of St Martin's Press LLC, 175 Fifth Avenue, New York, NY 10010.

Palgrave Macmillan is the global academic imprint of the above companies and has companies and representatives throughout the world.

Palgrave ${ }^{\circledR}$ and Macmillan ${ }^{\circledR}$ are registered trademarks in the United States, the United Kingdom, Europe and other countries.

ISBN: 978-0-230-23653-0 hardback

This book is printed on paper suitable for recycling and made from fully managed and sustained forest sources. Logging, pulping and manufacturing processes are expected to conform to the environmental regulations of the country of origin.

A catalogue record for this book is available from the British Library.

A catalog record for this book is available from the Library of Congress.

$\begin{array}{lllllllllll}10 & 9 & 8 & 7 & 6 & 5 & 4 & 3 & 2 & 1\end{array}$

$\begin{array}{llllllllll}19 & 18 & 17 & 16 & 15 & 14 & 13 & 12 & 11 & 10\end{array}$

Printed and bound in Great Britain by

CPI Antony Rowe, Chippenham and Eastbourne 


\title{
The Role of Virtual Integration, Commitment, and Knowledge-Sharing in Improving International Supplier Responsiveness
}

\author{
Ruey-Jer 'Bryan' Jean and Rudolf R. Sinkovics
}

\section{Introduction and motivation}

Globalization has triggered significant structural strategy shifts of multinational enterprises (MNEs). With increasing global competition, MNEs have disintegrated their value-adding activities with their suppliers or subcontractors around the world (Buckley and Ghauri, 2004; Sturgeon, 2002). As a function of this mega-trend, the issue of how MNEs can effectively coordinate and control their global supply chain relationships with local suppliers becomes a critical task for MNE efficiency and competiveness.

In the supply chain literature, responsiveness has become one of the most important performance metrics for managers in today's time-based competition era (Handfield and Bechtel, 2002; Hult, Ketchen, and Slater, 2004). With increasing demands from global customers, industrial suppliers or contract manufacturers have been pushed to respond more quickly and effectively to their international MNE customers. Interestingly, despite the overarching importance of supply chain responsiveness, the issue of how international supply chain partners can govern their transactions to enhance supplier responsiveness has not received widespread recognition in the literature (Hult et al. 2004). To this end, the main question of this research is 'What is the impact of specific governance mechanisms on supplier responsiveness in international customer-supplier relationships?'

Previously, several governance mechanisms have been identified that drive value creation in international channel relationships, such as, for example, relational norms, contracts, and knowledge-sharing (Cavusgil, Deligonul, and Zhang, 2004; Wu et al. 2007). Additionally, supply chain partners have embraced 
information technologies (IT) and adopted these with a view to enhance supply chain performance through higher levels of process and information integration. Virtual integration of supply chain partners via IT has been considered a structural dimension of governance which can help control and relationship building in exchange relationships (Wang and Hsiao-Lan, 2007; Wang, Tai, and Wei, 2006). Therefore, improved understanding of how IT can impact on vertical governance mechanisms and generate interorganizational governance value is essential for firms. This study seeks to develop and test a model to explore the effects of three forms of governance that may be employed to generate higher supplier responsiveness in international customer-supplier relationships: virtual integration, commitment, and knowledge-sharing. In doing so, we aim to contribute to relevant literature in two ways: first, rather than focusing on costminimization of governance which transactional cost economics (TCE) proposed (Williamson, 1975), drawing from resource-based view (RBV) (Barney, 1991), this study focuses on the value and performance effect of governance, which is still limited in the extant literature. Second, we advance out knowledge on the effectiveness of plural forms of governance to realize the full potential of vale creation in international channel relationships.

The context in which we investigate this issue is that of upstream supply chain relationships between MNEs and their contracting suppliers. Specifically, the relationship between international MNE customers and their OEM suppliers in Taiwan is used. This context helps to elucidate key managerial in the globally dispersed supply and value chain (Choe, 2008; Handfield and Nichols, 2004; Myers and Cheung, 2008). Survey methodology was pursued and structural equation modelling was employed to analyze the data.

The paper will be structured as follows. We start with a conceptual framework, where we define supply chain responsiveness and develop hypotheses relating the interrelationships between three different forms of governance mechanisms including virtual integration, commitment, and knowledgesharing. Moreover, we also develop hypotheses which address the impact of different governance mechanisms on value creation in terms of supplier responsiveness in international customer-supplier relationships. We then follow with an empirical study that tests the framework and its hypotheses. We report the findings and discuss the implications for theory and managers. We conclude by outlining this study's limitation and areas for future research.

\section{Conceptual framework}

As shown in Figure 2.1, drawing from resource-based view and transaction cost economic (TCE) and following the emerging view of governance value analysis, we propose that three different governance mechanisms - virtual integration, commitment, and knowledge-sharing - can stimulate interorganizational 


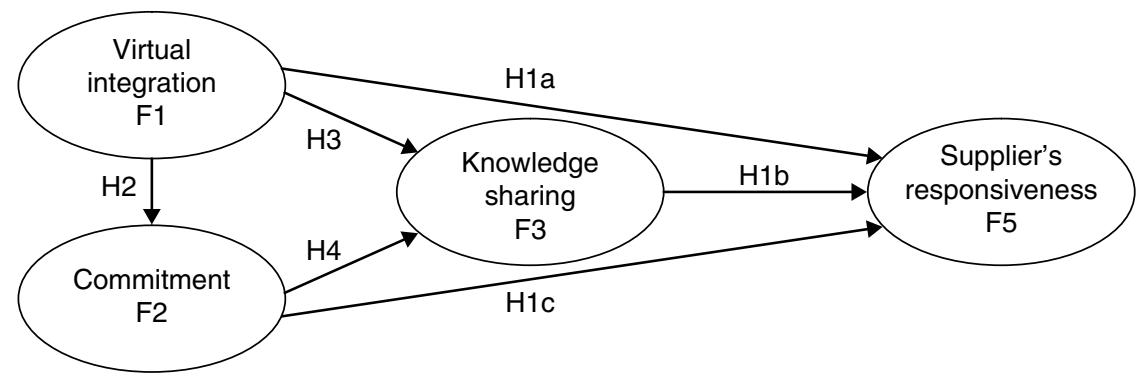

Figure 2.1 Conceptual framework

value in terms of supply chain responsiveness. Various governance mechanisms have been proposed for minimizing the cost of transactions in interfirm relationships (Cavusgil et al. 2004; Wu et al. 2007). We select these three governance mechanisms because they represent a wider spectrum of governance modes that capture technological, sociological, and information aspects of relationship management, respectively. We also argue that different governance mechanisms can complement and reinforce each other in the process of interorganizational value creation.

\section{Responsiveness}

Supplier responsiveness, the ultimate outcome variable in this study, is defined as the extent to which suppliers are effective in marshalling and redeploying resources in their attempt to respond quickly to environmental changes (Fang et al. 2008; Handfield and Bechtel, 2002). In supply chain relationships, cycle time reduction has been regarded as one of the most important outcome variables (Hult, Ketchen, and Arrfelt, 2007; Hult et al. 2004). Today's complicated and dynamic business environment requires suppliers to develop cycle timebased capability to deal with competitive and changing situations to satisfied demanding global customers. Parallel with dynamic capability theory, responsiveness can be one of the most important dynamic capabilities which help firms to achieve greater competiveness ahead of others. Researchers have demonstrated that higher supplier responsiveness links contribute to improving customer satisfaction (Handfield and Bechtel, 2002) and enhancing market performance (Kim, Cavusgil, and Calantone, 2006).

\section{Governance mechanisms}

Researchers have explored governance mechanisms that exist between organizations (Heide, 1994; Weitz and Jap, 1995) and within organizations (Ouchi 
1980). Traditional TCE proposed that governance decisions of firms are based on either pure market or hierarchy. More recently, researchers have examined the effectiveness of hybrid governance mechanisms, which are between pure market and hierarchy, for governing interfirm relationships as the transactional context becomes increasingly complex. In the international context, particularly, scholars highlighted that relational governance dimensions such as trust and commitment are important hybrid structures that allow international exchange partners to cope with uncertainty including cultural and geographical distance (Skarmeas, Katsikeas, and Schlegelmilch, 2002). Moreover, Wu et al. (2007) hold that knowledge-sharing can also serve as a relational governance mechanism between exchange partners in which the partners coordinate their activities to increase the potential for higher performance. Recent work suggests that IT can reduce transaction cost and create hybrid governance forms between markets and hierarchies (Jean, Sinkovics, and Kim, 2008; Kim and Mahoney, 2006). Therefore, this study focuses on commitment, knowledge-sharing, and virtual integration as three important hybrid governance mechanisms for governing international customersupplier relationships.

\section{Research hypotheses}

\section{The impact of different governance mechanisms on supplier responsiveness}

\section{Virtual integration}

The advancement of Internet and B2B technology has changed and restructured interfirm relationships. Virtual integration in this study refers to the extent to which firms conduct supply chain activities via virtual interconnectivity through Internet and B2B technology with their exchange partners (Jean et al. 2008; Wang and Hsiao-Lan, 2007; Wang et al. 2006). These virtual integrations involve activities ranging from online billing, checking ordering status, inventory levels etc. in supply chain relationships. It is one type of quasi-integration and is considered as part of governance structures in many studies (Wang et al. 2006; Zaheer and Venkatraman, 1994).

Because virtual integration can enhance information processing capabilities and reduces transaction cost, a higher level of virtual integration allows exchange parties to share more timely and more accurate information. Moreover, because all the joint actions between channel partners are information-intensive, online virtual integration can increase information visibility within supply chain relationships and thus improve all relevant coordination activities (Kim et al. 2006; Wang et al. 2006). Both coordination and information visibility-enhancing effects of virtual integration 
(Yamin and Sinkovics, 2007) can help suppliers to achieve more adaptive and flexible relationships with their international customers. Thus,

Hypothesis 1a: The greater the virtual integration in international customersupplier relationships, the greater the supplier responsiveness.

\section{Knowledge-sharing}

In this study, knowledge-sharing is defined as the extent to which the supplier and its international customer work together in joint exchange of information and know-how, analyzing and solving operational and strategic issues and problems to facilitate communication about the relationship (Wu et al. 2007). This reflects a process dimension of bilateral governance that involves the parties carrying out joint cooperative efforts which can help reduce transaction costs and deter opportunistic behaviours in the relationships (Cavusgil et al. 2004; Chang and Gotcher, 2007), which follows the transaction cost perspective (TCE) (Williamson, 1979).

The process of knowledge-sharing can result in the formation of relationship norms that help to reduce the need for and cost of monitoring in the exchange process (Wu et al. 2007). Thus, knowledge-sharing can serve as relational governance mechanism between channel partners which enhances confidence to cooperate and coordination efforts. Building on RBV's notion of value, rarity, and inimitability, the knowledge-based view argues that unique abilities to create and exploit knowledge can deliver competitive advantage and thereby enhance outcomes. In the supply chain context, Hult et al. (2007) find that knowledge development has a positive effect on supply chain responsiveness. Hence,

Hypothesis 1b: The greater the knowledge-sharing in international customersupplier relationships, the greater the supplier responsiveness.

\section{Commitment}

Commitment in this study refers to an exchange partner belief that an ongoing relationship with another party is important and thus a maximum effort in terms of maintaining it is warranted (Morgan and Hunt, 1994). Studies have shown that relationship commitment represents an essential part of successful long-term business relationships. It facilitates the smooth organization and coordination of economic activates between trading parties (Morgan and Hunt, 1994). In international customer-supplier relationships, a supplier that is committed to its overseas customer can serve a mechanism for reducing transaction cost also promote the willingness of partners to perform recurrent transactions and thus permit flexibility when a trading partner introduces extra requirement. Such flexibility allows efficient interfirm coordination and adaptation to environment changes. Commitment was regarded as a relational 
governance mechanism which is manifested in its flexibilities-enabling feature as a form of cooperative behaviour (Skarmeas et al. 2002). Empirical studies also find that commitment is a critically important element for improving international channel performance (Skarmeas et al. 2002). Therefore,

Hypothesis 1c: The greater the supplier commitment in international customersupplier relationships, the greater the supplier responsiveness.

\section{Interrelationships between different governance mechanisms}

\section{The relationship between virtual integration and commitment}

Virtual integration in international customer-supplier relationships requires both suppliers and their international customer to invest a lot of fiscal and nonfiscal investments including systems, personnel, and knowledge which are specific to the exchange relationships. Such relationship assets are highly specialized and impossible or difficult to redeploy to an alternative exchange arrangement. This specificity forces firms to try their best to maintain the relationship in order to keep and enhance the value of their investments in the relationships (Wang and Hsiao-Lan, 2007). Previous research showed that transactional specific investment can create a lock-in effect and bind firms together constructively in exchange relationships (Anderson and Weitz, 1992). Accordingly, virtual integration was regarded as a relationship-specific investment which can enhance mutual commitment in business exchange relationships (Kim and Mahoney, 2006). Hence, it is hypothesized that:

Hypothesis 2: The greater the virtual integration in the international customersupplier relationship, the greater the supplier commitment to the relationship.

\section{The relationship between virtual integration and knowledge-sharing}

Some researchers have linked the impact of IT to knowledge-sharing (Kane and Alavi, 2007; Real, Leal, and Roldán, 2006; Tippins and Sohi, 2003). Most of them argue that IT can enhance the quality and quantity of information exchange within and between firm boundaries (Kim et al. 2006) and thus can facilitate greater knowledge-sharing. In the context of supply chains and buyer-seller relationships, electronic integration is expected to assist joint learning activities like information exchange and joint sense making. Unlike traditional Electronic Data Interchange (EDI), new formats of Internet-based IT systems in SCMs allows firms to link up with a large number of supply chain partners and exchange rich information that goes beyond day-to-day operational levels. Moreover, advanced IT in SCMs like collaborative planning, forecasting, and replenishment (CPFR) can help uncover patterns in data and help in the processing of large quantities of raw data. Such IT-based systems can help interpret information in a timely and accurate way for the whole 
supply chain members (Malhotra, Gosain, and Sawy, 2005). Further, enterprise resource planning (ERP) systems, include advanced databases which allows firms to tap into previously stored information received from external sources in order to create new knowledge in exchange relationships (Malhotra et al. 2005). Building on the above arguments, we posit:

Hypothesis 3: The greater the virtual integration in the international customersupplier relationship, the greater the knowledge-sharing in the relationship.

\section{The relationship between supplier commitment and knowledge-sharing}

High levels of commitment can encourage suppliers to become more deeply involved in interactions with international customers by devoting additional resources to their international exchange relationships, which, in turn, are expected in enhanced knowledge-sharing activities. It has been suggested that partner commitment and shared vision is related to collaborative learning activities (Dyer and Singh, 1998). Recent studies also find that commitment has a positive effect on relationships learning (Selnes and Sallis, 2003). Therefore,

Hypothesis 4: The greater the supplier's commitment to the international customersupplier relationships, the greater the knowledge-sharing in the relationship.

\section{Methodology}

\section{Empirical context and data collection}

The empirical context of this paper is international customer-supplier relationships between Taiwanese OEM/ODM suppliers and their international buyers in the electronics industry, a type of international subcontracting relationship. Our focus is on a particular OEM/ODM supplier's action, in the form of their responsiveness, to the form of exchange relationships with their international customers with regard to international governance strategy including coordination efforts, control, trust and virtual integration. We deliberately focus on the electronics industry in Taiwan as empirical context because members in electronics industry are firms that pioneer the development of information technology and make great IT investments in supply chain management. Moreover, the structure of the ODM/ODM electronics supplying network is characterized by significant asymmetric bargaining relationships between international customers and their local suppliers (Kang, Mahoney, and Tan, 2009).

We collected data through a cross-sectional survey. The sampling frame for the survey comprised of all electronic companies from the year 2007 directory of the Top 5000 Largest Firms in Taiwan, published by China Credit Information Service Ltd (a total of 1069 companies). This database covers a range of electronics companies including communication products, semiconductors, computer 
components, and peripherals, and so on. All 1069 firms were contacted to assess their eligibility and locate appropriate informants for the study.

Data was obtained through a key informant technique, which has been deployed in prior studies on interorganizational issues (Kumar, Stern, and Anderson, 1993). Key informants in this study are senior account managers and marketing managers who are in charge of maintaining relationship with international customers and have knowledge about IT investment in supply chain relationships. We also assessed their familiarity with the themes raised in the questionnaire to ascertain appropriate responses.

The survey was conducted in two waves. Four weeks after the first mailing of questionnaires and introductory letter, reminder letters and questionnaires were sent out to no respondents. As result, 219 useable questionnaires were received, for a response rate of $20 \%$.

Nonresponse bias was assessed by a comparison of (1) sample statistics to known values of the population, such as annual sales volume and number of employees, and (2) firs and second wave data (Armstrong and Overton, 1977). Neither procedure revealed significant different between sampled and target populations.

Descriptive information about of the respondents is shown in Table 2.1.

Table 2.1 Characteristics of responding firms

\begin{tabular}{lrlr}
\hline Product distribution & Percentage & Sales revenue & Percentage \\
\hline Communication products & 12.2 & NT100M-NT500M (US \$3M) & 19.1 \\
Systems & 6.5 & NT501-NT1B & 15.9 \\
Computer peripherals & 14.2 & NT1B-NT5B & 39.0 \\
Optoelectronics & 14.6 & NT5B-NT10B & 7.3 \\
Semiconductors & 15.9 & More than NT10B (US \$300M) & 18.7 \\
Computer components & 36.6 & Total & 100 \\
Total & 100 & Length of international & \\
Employee numbers & & partnerships & \\
& & & 4.5 \\
Less than 100 & 20.3 & Less than 1 year & 8.9 \\
$100-199$ & 21.1 & 1-2 years & 39 \\
$200-499$ & 26.4 & 3-5 years & 35 \\
$500-999$ & 13 & 6-10 years & 12 \\
$1000-4999$ & 14.6 & 11 years and above & \\
$5000-9999$ & 1.6 & Country of origin of & \\
10000 and above & 2.8 & international customers & \\
Total & 100 & America & 43.5 \\
& & Asia & 22.9 \\
\hline
\end{tabular}




\section{Questionnaire development and measures}

Global supply chain management research is relatively new in terms of theoretical development (Samiee, 2008). Therefore, to create the survey items, 15 in-depth interviews were conducted with 15 senior OEM/ODM account or marketing managers or directors. Additionally, to balance the dyadic point of view in international subcontracting, we also conducted two interviews with branded electronics international buyers. These interviews, along with and extensive review of the literature, were used to develop the questionnaire.

Overall, all constructs in the model were measured with multiple-item reflective scales. In general, well-validated measures reported in previous top marketing, international business and strategic management journal were used. We also followed Churchill's (1979) multiple-steps and multi-validation methods to modify and develop the items for key construct in the conceptual framework. For all scales, each item was measured using a 7-point Likert scale ( 7 = strongly agree, $1=$ strongly disagree).

As shown in Table 2.2, virtual integration was measure by four items, building on the work by Wang et al. (2006) and adapted to the cross-border context in the study. A 4-item scale was used to measure trust. It was taken from Morgan and Hunt (1994) and adapted to our context. Knowledge-sharing was measured by four items assessing the joint activities between exchange partners in which the partners share information that is jointly interpreted to generate mutually shared behaviour. The items were adapted from Chen et al. (2009) work. Finally, supplier's responsiveness was measured by four items which modified from Kim et al (2006) and Handfield and Bechtel's (2002) work. The items were used to capture suppliers' capability to quickly respond's to their international customers' need.

\section{Reliability and validity}

A confirmatory factor analysis was carried out to investigate the convergent and discriminant validity of each construct in the proposed conceptual model (Bentler, 2005). The measurement model including all constructs was fitted by the estimated procedure of the EQS program (Bentler, 2005).The results of the analysis are shown in Table 2.2. The model provides a good fit given the complex nature of the second-order confirmatory factor analysis $(\mathrm{CHI}-\mathrm{SQUARE}=$ 282.866 with degree of freedom (d.f.) $=137$; $\mathrm{CFI}=0.945 ; \mathrm{NFI}=0.945 ; \mathrm{NNFI}=$ 0.931; RMSEA $=0.071)$. Moreover, all items loaded on their respective constructs are statistically significant. Further, the composite reliability for all constructs was above the 0.7 level (shown in Table 2.2) suggested by Hair et al. (2006), indicating adequate reliability for each construct.

Moreover, all factors loadings were statistically significant at the 5\% level, and all of the factor loadings exceed the arbitrary 0.5 standard (Fornell and Larcker, 1981a), as shown in Table 2.2. Thus, these measures demonstrate 
Table 2.2 Results of CFA

\begin{tabular}{|c|c|c|}
\hline Construct and measures & $\begin{array}{l}\text { Std. factor } \\
\text { loadings }\end{array}$ & $\begin{array}{l}\text { Composite reliability } \\
(\alpha) \text { (Average Variance } \\
\text { Extraction) }\end{array}$ \\
\hline Virtual integration & & $0.865(0.570)$ \\
\hline $\begin{array}{l}\text { Our international customer accesses or } \\
\text { traces our shipping/delivery schedule } \\
\text { electronically. }\end{array}$ & 0.598 & \\
\hline $\begin{array}{l}\text { Our international customer monitors our } \\
\text { quality of product electronically. }\end{array}$ & 0.680 & \\
\hline $\begin{array}{l}\text { We exchange product price and market } \\
\text { information with our international } \\
\text { customer electronically. }\end{array}$ & 0.645 & \\
\hline $\begin{array}{l}\text { We and our international customer } \\
\text { coordinate production plans with each } \\
\text { other electronically. }\end{array}$ & 0.899 & \\
\hline Commitment & & $0.885(0.658)$ \\
\hline $\begin{array}{l}\text { We believe the information that our } \\
\text { international customer provides us. }\end{array}$ & 0.765 & \\
\hline $\begin{array}{l}\text { Our international customer is genuinely } \\
\text { concerned that our business succeeds. }\end{array}$ & 0.882 & \\
\hline $\begin{array}{l}\text { We trust our international customer keeps } \\
\text { our best interests in mind. }\end{array}$ & 0.765 & \\
\hline Our international customer is trustworthy. & 0.827 & \\
\hline Knowledge-sharing & & $0.768(0.530)$ \\
\hline $\begin{array}{l}\text { It is common to establish joint teams to } \\
\text { analyze and discuss strategic issues. }\end{array}$ & 0.579 & \\
\hline $\begin{array}{l}\text { The atmosphere in the relationship } \\
\text { stimulates productive discussion } \\
\text { encompassing a variety of opinions. }\end{array}$ & 0.771 & \\
\hline $\begin{array}{l}\text { We have a lot of face-to-face } \\
\text { communication in this relationship. }\end{array}$ & 0.812 & \\
\hline $\begin{array}{l}\text { In this relationship, we frequently adjust } \\
\text { our common understanding of trends in } \\
\text { technology related to our business. }\end{array}$ & 0.703 & \\
\hline Supplier's responsiveness & & $0.893(0.676)$ \\
\hline $\begin{array}{l}\text { Compared to our competitors, our supply } \\
\text { chain responds more quickly and } \\
\text { effectively to changing major } \\
\text { international customer needs. }\end{array}$ & 0.838 & \\
\hline
\end{tabular}




\begin{tabular}{lcc}
\hline Construct and measures & $\begin{array}{c}\text { Std. factor } \\
\text { loadings }\end{array}$ & $\begin{array}{l}\text { Composite reliability } \\
(\alpha) \text { Average Variance } \\
\text { Extraction) }\end{array}$ \\
\hline $\begin{array}{l}\text { Compared to our competitors, our supply } \\
\text { chain develops and markets new products } \\
\text { more quickly and effectively. }\end{array}$ & 0.783 & \\
$\begin{array}{l}\text { We have the ability to deal with orders for } \\
\text { our international customer in a short lead } \\
\text { time. }\end{array}$ & 0.870 & \\
$\begin{array}{l}\text { We have the ability to be outstanding in } \\
\text { on time delivery for our international } \\
\text { customer. }\end{array}$ & 0.794 & \\
\hline
\end{tabular}

CFA Model Goodness of Fit Indexes: CHI-SQUARE $=282.866$ and with degree of freedom(d.f.) $=137$; Comparative Fit Index $(\mathrm{CFI})=0.945$; Bollen Fit Index $=0.945$; Bentler-Bonett Non-Normed Fit Index $($ BBNNFI $)=0.931$; root mean square of approximation $($ RMSEA $)=0.071 ; 90 \%$ confidence of RMSEA $(0.059 ; 0.082)$.

Table 2.3 Mean, SD, inter-construct correlations, and average variance extracted $(\mathrm{n}=219)$

\begin{tabular}{lccccc}
\hline & Mean (S.D.) & F1 & F2 & F3 & F4 \\
\hline F1 Virtual integration & 4.560 & $\mathbf{0 . 7 5 4}$ & & & \\
& $(1.032)$ & & & & \\
F2 Commitment & 5.560 & 0.054 & $\mathbf{0 . 8 1 1}$ & & \\
& $(1.107)$ & & & & \\
F3 Knowledge-sharing & 5.236 & $0.239^{* *}$ & $0.432^{* *}$ & $\mathbf{0 . 7 2 8}$ & \\
& $(0.928)$ & & & & \\
F4 Responsiveness & 5.675 & $0.254^{* *}$ & $0.495^{* *}$ & $0.602^{\star *}$ & $\mathbf{0 . 9 0 4}$ \\
& $(1.124)$ & & & & \\
\hline
\end{tabular}

Note: Numbers in bold denote the square root of the average Variance extracted (AVE), ${ }^{* *}=\mathrm{p}<0.01$

adequate convergent validity. In terms of discriminant validity, this study assessed the discriminant validity of each construct in two ways (Wu et al. 2007). First, a procedure recommended by Bagozzi, Yi, and Phillips (1991) was adopted. We examined pairs of related constructs in a two-factor CFA, once constraining the correlations between two constructs to unity and once freeing this parameter. Then a chi-square difference test was conducted. The results indicated that the chi-square values were significantly lower for the unstrained models at the $5 \%$ level, which suggest that the constructs exhibit discriminant validity. This study also checked the methods suggested by Fornell and Larcker (1981b). As shown in Table 2.3, the square root of the average variance extracted is greater that all corresponding correlations, which indicates adequate discriminant validity. 


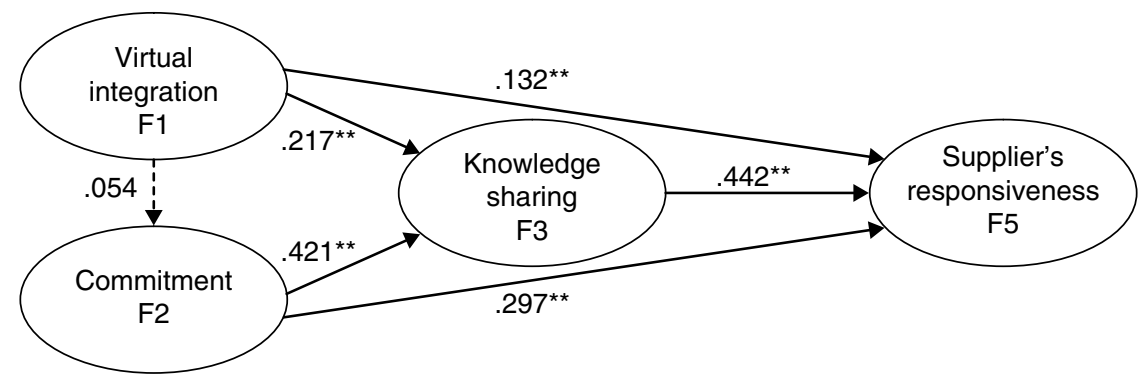

Chi-square: $247.615, d f=97$, NNFI: 0.918, IFI: 0.935, CFI: 0.934, RMSEA:0.081 ${ }^{*} p<0.05 ;{ }^{* *} p<0.01$, Dashed line indicates insignificant paths.

Figure 2.2 Structural model

Table 2.4 Summary of hypothesis test results

\section{Hypothesis}

Results

H1a: The greater the virtual integration in international customer-

Supported supplier relationships, the greater the supplier responsiveness.

H1b: The greater the knowledge-sharing in international customer-

Supported supplier relationships, the greater the supplier responsiveness.

H1c: The greater the supplier commitment in international customer- Supported supplier relationships, the greater the supplier responsiveness.

$\mathrm{H} 2$ : The greater the virtual integration in the international

Not customer-supplier relationship, the greater the supplier supported commitment to the relationship.

H3: The greater the virtual integration in the international Supported customer-supplier relationship, the greater the knowledge-sharing in the relationship.

H4: The greater the supplier commitment in the international customer-supplier relationship, the greater the knowledge-sharing in the relationship.

\section{Structural model test results}

Figure 2.2 presents results of the structural tested evaluating overall model fit. The overall fit statistics indicate a very good fit for the full model (Chi-square: 257.615, df = 97, NNFI: 0.918, IFI: 0.935, CFI: 0.934, RMSEA: 0.081). Regarding the hypothesis relationships, consistent with the claim of Hypothesis 1a, 1b, and 1c, virtual integration, knowledge-sharing, and commitment have positive and significant impacts on supplier responsiveness. 
$(\mathrm{t}=4.323, p<0.1),(\mathrm{t}=6.379, p<0.1),(\mathrm{t}=2.142, p<0.05)$, respectively. Thus, the results suggest that Hypothesis $1 \mathrm{a}, 1 \mathrm{~b}$, and $1 \mathrm{c}$ are all supported. The path coefficient from virtual integration to commitment is .045 $(\mathrm{t}=.730 ; p>0.1)$, which does not support Hypothesis 2. We will provide possible explanation for this result in the next section. The path coefficient from virtual integration to knowledge-sharing is 0.2197 ( $t=2.978, p<0.01)$, which supports Hypothesis 3. We tested a positive effect of supplier commitment on knowledge-sharing with Hypothesis 4 . According to the result, supplier commitment facilitates knowledge-sharing in international customer-supplier relationships $(p<0.01)$, as expected in Hypothesis 4 . All the summary of hypotheses test results was shown in Table 2.4.

\section{Discussion and implications}

Although different governance mechanisms and their impacts on cost minimization in interfirm relationships has been examined by previous studies, which based on TCE, there is limited understanding the roles of that governance mechanisms play in interorganizational value creation in international exchange relationships. This study adds to the contemporary knowledge based RBV by providing an explanation of how different governance mechanisms including virtual integration, knowledge-sharing and commitment impact on supplier responsiveness in international customer-supplier relationships. The model was tested using data collected from Taiwanese electronics suppliers in relationships with international customers. The results support most hypotheses but fail to support the link between virtual integration and commitment. Based on the findings, a number of guidelines can be offered to both scholars and practitioners regarding the theoretical and managerial implications.

\section{Interorganizational governance value creation through effective governance mechanism}

First of all, we postulated that different governance mechanisms including virtual integration, knowledge-sharing, and commitment will facilitate supplier responsiveness in international customer-supplier relationships. The hypotheses are all supported. The results suggest that different governance mechanisms including relational, technology, and information aspects of governance can contribute to supplier responsiveness in the exchange relationships. This is consistent with the view of plural forms of governance in the value creation process in the exchange relationships (Wu et al. 2007). Firms can simultaneously use different governance approaches to create value in terms enhancing supplier responsiveness in international exchange relationships. Moreover, among different hybrid governance mechanisms, 
we find that knowledge-sharing has the strongest positive effect on supplier responsiveness, following by commitment and virtual integration. The results indicated that knowledge-sharing play the most effective role in interorganizational governance value creation in international exchange relationships. This is consistent with Myer and Cheung's (2008) recent findings that the crucial role of knowledge-sharing plays in creating vale in global supply chain relationships. Moreover, the results show that relational governance such as relationship commitment is also crucial in facilitating suppler responsiveness. This contributes the emerging stream of research highlighting the importance and the performance enhancement of relational norm in governing international exchange relationships (Cavusgil et al. 2004). In additional, the findings also indicate that virtual integration can facilitate supplier responsiveness in the international customer-supplier relationships. This sheds some lights on the debate and inconsistent findings on performance implications of IT investment in supply chain relationships (Kim et al. 2006).

\section{Interrelationships between different governance mechanisms}

In addition to a direct impact of three different governance mechanisms including virtual integration, knowledge-sharing, and commitment on value creation in international customer-supplier relationships, this study investigates the interrelationships between different governance. Whether different governance mechanisms function as complements or substitutes can be an intriguing research question. The findings of this study reveal that virtual integration and commitment can facilitate knowledge-sharing in international customer-supplier relationships, which in turn, can lead to greater supplier responsiveness. Knowledge-sharing not only has the strongest direct impact on supplier responsiveness, but it also plays a key mediating role for technology and relationship aspect of governance mechanism. The findings contribute to the emerging stream of research on the interacting and mediating effect of knowledge management with other capabilities in supply chain relationships.

In terms of the relationships between virtual integration and commitment, the empirical findings do not support the positive link. One line of speculation for the lack of positive link between virtual integration and commitment pertains to the firm's potential lock in risk of virtual integration in the exchange relationship (Saraf, Langdon, and Gosain, 2007). Virtual integration can reduce firm's flexibility, make firms change partners more difficult and costly, and limit the specificity facilitating capability of virtual integration in international customer-supplier relationships. Therefore, virtual integration may not be able to serve as an effective mechanism in enhancing relationship commitment in the exchange relationships. 


\section{Limitations and future research}

As research is always messy and never perfect, several limitations of this study have to be acknowledged. Firstly, this study only adopted one perspective in the dyadic supply chain relationship, focusing on perceptual data from a supplier's perspective. This raises a potential bias and future research may complement this research by examining our proposed model from the international customers' perspectives. Secondly, this study is based on cross-sectional data. Given significant advantages of longitudinal data over cross-sectional data (Rindfleisch et al. 2008) future longitudinal research is encouraged, as it may provide valuable insight into the dynamic nature of IT, commitment, and knowledge-sharing facilitated responsiveness in international channel relationships. Finally, this study only examines commitment and virtual integration as antecedents of knowledge-sharing and determinants of supplier's responsiveness. Other potential variables such as contracts or dependence (Handfield and Bechtel, 2002) should be examined in the future.

\section{References}

Anderson, E. and Weitz, B. (1992) 'The use of pledges to build and sustain commitment in distribution channels', Journal of Marketing Research, 29(1), 18-43.

Armstrong, J.S. and Overton, T. S. (1977) 'Estimating nonresponse bias in mail surveys', Journal of Marketing Research, 14(3), 396-402.

Bagozzi, R.P., Yi, Y. and Phillips, L.W. (1991) 'Assessing construct validity in organizational research', Administrative Science Quarterly, 36(3), 421-58.

Barney, J. (1991) 'Firm resources and sustained competitive advantage', Journal of Management, 17(1), 99-120.

Bentler, P.M. (2005) EQS 6 Structural Equations Program Manual. Encino, CA: Multivariate Software Inc.

Buckley, P.J. and Ghauri, P.N. (2004) 'Globalisation, economic geography and the strategy of multinational enterprises', Journal of International Business Studies, 35(2), 81-98.

Cavusgil, S.T., Deligonul, S. and Zhang, C. (2004) 'Curbing foreign distributor opportunism: An examination of trust, contracts, and the legal environment in international channel relationships', Journal of International Marketing, 12(2), 7-27.

Chang, K.-H. and Gotcher, D.F. (2007) 'Safeguarding investments and creation of transaction value in asymmetric international subcontracting relationships: The role of relationship learning and relational capital', Journal of World Business, 42(4), 477-88.

Chen, Y.-S., Lin, M.-J. J. and Chang, C.-H. (2009) 'The positive effects of relationship learning and absorptive capacity on innovation performance and competitive advantage in industrial markets', Industrial Marketing Management, 38(2), 152-58.

Choe, J.-M. (2008) 'Inter-organizational relationships and the flow of information through value chains', Information \& Management, 45(7), 444-50.

Churchill, G.A. (1979) 'A paradigm for developing better measures of marketing constructs', Journal of Marketing Research, 16(1), 64-73.

Dyer, J.H. and Singh, H. (1998) 'The relational view: Cooperative strategy and sources of interorganizational competitive advantage', Academy of Management Review, 23(4), 660-79. 
Fang, E., Palmatier, R.W., Scheer, L.K. and Li, N. (2008) 'Trust at different organizational levels', Journal of Marketing, 72(2), 80-98.

Fornell, C. and Larcker, D.F. (1981a) 'Structural equation models with unobservable variables and measurement error: Algebra and statistics', Journal of Marketing Research, $18(3), 382-88$.

Fornell, C. and Larcker, D.F. (1981b) 'Evaluating structural equation models with unobservable variables and measurement error', Journal of Marketing Research, 18(1), 39-50.

Hair, J. F., Black, W.C., Babin, B.J., Anderson, R.E. and Tatham, R.L. (2006) Multivariate Data Analysis, 6th ed. Upper Saddle River, NJ: Prentice Hall.

Handfield, R.B. and Bechtel, C. (2002) 'The role of trust and relationship structure in improving supply chain responsiveness', Industrial Marketing Management, 31(4), 367-82.

Handfield, R.B. and Nichols, E.L. Jr (2004) 'Key issues in global supply base management', Industrial Marketing Management, 33(1), 29-35.

Heide, J.B. (1994) 'Interorganizational governance in marketing channels', Journal of Marketing, 58(1), 71-85.

Hult, G.T.M., Ketchen, D.J. and Slater, S.F. (2004) 'Information processing, knowledge development, and strategic supply chain performance', Academy of Management Journal, 47(2), 241-53.

Hult, G.T.M., Ketchen, D.J. and Arrfelt, M. (2007) 'Strategic supply chain management: Improving performance through a culture of competitiveness and knowledge development', Strategic Management Journal, 28(10), 1035-52.

Jean, R.-J. 'Bryan', Sinkovics, R.R. and Kim, D. (2008) 'Information technology and organizational performance within international business to business relationships: A review and an integrated conceptual framework', International Marketing Review 25(5), 563-83.

Kane, G.C. and Alavi, M. (2007) 'Information technology and organizational learning: An investigation of exploration and exploitation processes', Organization Science, 18(5), 796-812.

Kang, M.-P., Mahoney, J.T. and Tan, D. (2009) 'Why firms make unilateral investments specific to other firms: The case of OEM suppliers', Strategic Management Journal, 30(2), 117-35.

Kim, D., Cavusgil, S.T. and Calantone, R.J. (2006) 'Information system innovations and supply chain management: Channel relationships and firm performance', Journal of the Academy of Marketing Science, 34(1), 40-54.

Kim, S.M. and Mahoney, J.T. (2006) 'Mutual commitment to support exchange: Relationspecific it system as a substitute for managerial hierarchy', Strategic Management Journal, 27(5), 401-23.

Kumar, N., Stern, L.W. and Anderson, J.C. (1993) 'Conducting interorganizational research using key informants', Academy of Management Journal, 36(6), 1633-51.

Malhotra, A., Gosain, S. and Sawy, O.A. El (2005) 'Absorptive capacity configurations in supply chains: Gearing for partner-enabled market knowledge creation', MIS Quarterly, 29(1), 145-87.

Morgan, R.M. and Hunt, S.D. (1994) 'The commitment-trust theory of relationship marketing', Journal of Marketing, 58(3), 20-38.

Myers, M.B. and Cheung, M.-S. (2008) 'Sharing global supply chain knowledge', MIT Sloan Management Review, 49(4), 67-73.

Real, J.C., Leal, A. and Roldán, J.L. (2006) 'Information technology as a determinant of organizational learning and technological distinctive competencies', Industrial Marketing Management, 35(4), 505-21. 
Rindfleisch, A., Malter, A. J., Ganesan, S. and Moorman, C. (2008) 'Cross-sectional versus longitudinal survey research: Concepts, findings, and guidelines', Journal of Marketing Research, 45(3), 261-79.

Samiee, S. (2008) 'Global marketing effectiveness via alliances and electronic commerce in business-to-business markets', Industrial Marketing Management, 37(1), 3-8.

Saraf, N., Langdon, C.S. and Gosain, S. (2007) 'Is application capabilities and relational value in interfirm partnerships', Information Systems Research, 18(3), 320-39.

Selnes, F. and Sallis, J. (2003) 'Promoting relationship learning', Journal of Marketing, 67(3), 80-95.

Skarmeas, D., Katsikeas, C. S. and Schlegelmilch, B.B. (2002) 'Drivers of commitment and its impact on performance in cross-cultural buyer-seller relationships: The importers perspective', Journal of International Business Studies, 33(4), 757-83.

Sturgeon, T. J (2002) 'Modular production networks: A new American model of industrial organization', Industrial and Corporate Change, 11(3), 451-96.

Tippins, M. J and Sohi, R.S (2003) 'IT competency and firm performance: Is organizational learning a missing link?', Strategic Management Journal, 24(8), 745-61.

Wang, E.T.G., Tai, J.C.F. and Wei, H.-L. (2006) 'A virtual integration theory of improved supply-chain performance', Journal of Management Information Systems, 23(2), 41-64.

Wang, Eric T.G. and Hsiao-Lan, Wei (2007) 'Interorganizational governance value creation: Coordinating for information visibility and flexibility in supply chains', Decision Sciences, 38(4), 647-74.

Weitz, B.A. and Jap, S.D. (1995) 'Relationship marketing and distribution channels', Journal of the Academy of Marketing Science, 23(4), 305-20.

Williamson, O.E. (1975) Markets and Hierarchies: Analysis and Antitrust Implications. New York: Free Press.

Williamson, O.E. (1979) 'Transaction-cost economics: The governance of contractual relations', Journal of Law and Economics, October, 233-61.

Wu, F., Sinkovics, R.R., Cavusgil, S.T. and Roath, A.S. (2007) 'Overcoming export manufacturer's dilemma in international expansion', Journal of International Business Studies, 38(2), 283-302.

Yamin, M. and Sinkovics, R.R. (2007) 'ICT and MNE reorganisation - the paradox of control', Critical Perspectives on International Business, 3(4), 322-36.

Zaheer, A. and Venkatraman, N. (1994) 'Determinants of electronic integration in the insurance industry: An empirical test', Management Science, 40(5), 549-57. 